\title{
Det motsägelsefulla utanförskapet
}

\section{CATHARINA ERIKSSON}

\begin{abstract}
Hemlösas situation beskrivs ofta med hiälp av metaforeratt "de finns därute", "i kylan" eller att "de lever utanför samhället". Denna artikel undersöker kvinnors erfarenheter av hemlöshet och utanförskap-erfarenheter som visar att hemlösa inte på något enkelt sätt kan ses som utanför samhället.
\end{abstract}

Under vintern 1998 när jag arbetade med att intervjua och läsa om hemlösa kvinnor tog jag på kvällarna bussen hem. Och varje kväll kunde jag läsa en reklamsnutt från Stadsmissionen på Göteborgs busstrafik. Texten löd: "Visst är det varmt och skönt där i bussen. Men det finns de som inte har det så varmt, som står utanför gemenskapen, ute i kylan." När man skall beskriva de hemlösas situation förekommer ofta en mängd metaforer - att "de finns därute", »i kylan", att de lever på "samhällets marginaler», på "samhällets botten» eller till och med i ssamhällets avgrund«. Alla dessa metaforer, inklusive definitionen hemlös, hjälper till att skapa en bild av de hemlösa och deras situation. Bilden av den trasige, smutsige hemlöse mannen som sover på gatan är

Catharina Eriksson är doktorand vid Sociologiska institutionen i Göteborg. Hon arbetar för närvarande med en avhandling om kvinnors erfarenheter av hem och hemlöshet. så vanlig att det är svårt att föreställa sig att hemlösa skulle se ut på något annat sätt. Ändå vet vi inte om de flesta hemlösa ser ut på detta sätt. Och även om de ibland står utanför våra dörrar i en mycket konkret bemärkelse så är de inte alltid utanför.

Artikeln inleds med en diskussion av den metod som använts samt en kortare presentation av de kvinnor som varit med $\mathrm{i}$ undersökningen. Därefter gör jag en presentation av begreppet utanförskap och dess relation till forskning om hemlöshet och där jag speciellt lyfter fram kvinnors situation. Detta följs av en analys av intervjuerna som syftar till att lyfta fram två olika dimensioner i de utanförskap som kvinnorna själva har talat om. I den första delen diskuteras kvinnornas

Artikeln ingår i ett tvåårigt forskningsprojekt som leddes av Abby Peterson kring kvinnors erfarenheter av utanförskap och hemlöshet och finansierades av HSFR under 1997-98. 
förhållande till myndigheter och i den andra delen hur de förhåller sig till det offentliga rummet. Artikel avslutas med en sammanfattande diskussion. Syftet med artikeln är att lyfta fram det motsägelsefulla i det utanförskap som kvinnorna erfar. Motsägelser av att känna sig både utanför och innanför, synlig och osynlig.

\section{Metod}

Denna artikel är en undersökning av erfarenheter av utanförskap som kvinnor som är eller har varit utan bostad upplever. ${ }^{1}$ Artikeln bygger på intervjuer som har gjorts med sju kvinnor i åldrarna 26-36 år varav

1 Inom hemlöshetsforskningen finns det en stor diskussion kring de metodologiska problem som forskningen med denna grupp inbegriper se t.ex. Swärd (1999) för en översikt av diskussionen. David Wagner (1993) har kritiserat undersökningar där forskaren endast gör en intervju med den bostadslöse, på t.ex. ett härbärge, för att blir allt för fokuserad på en krissituation i individens liv och därmed går miste om de processer som leder in och ut ur bostadslösheten. Han menar att det är mer fruktbart att följa en grupp bostadslösa under en längre tid för att kunna få en uppfattning om gruppens utveckling. Samtidigt som Wagner har en viktigt poäng $i$ att betona vikten av att ha ett långsiktigt perspektiv så är det nästan omöjligt att följa en grupp bostadslösa kvinnor i Sverige under lång tid - framförallt för att de flesta kvinnor rör sig sporadiskt mellan olika grupper av män, in och ut på institutioner osv. och därför sällan eller aldrig skapar en stark grupptillhörighet. Det är ändå möjligt, menar jag, att både ha ett långsiktigt perspektiv $i$ analys av de politiska förhållanden som kvinnorna rör sig i och i hur de får berätta sin livshistoria och ändå endast träffa kvinnorna vid ett tillfälle. Se även Carlen (1996) för en diskussion av Wagner. sex intervjuer ägde rum på kriminalvårdsinstitution och en på ett familjehem. Av dessa sju så var det två stycken som gick med på att träffa mig en andra gång. Orsaken till denna övervikt av kvinnor inom kriminalvården beror på att vi mötte oerhört stora svårigheter med att träffa kvinnor under andra omständigheter. En första barriär för att få tillstånd till en intervju utgjordes av personalen på de ställen där kvinnorna tillfälligt bodde, vilka inte alltid tillät oss att tillfråga kvinnorna om de ville vara med i undersökningen. Om personalen lät oss fråga dem var det sällan som kvinnorna själva ville ställa upp. Och även om de ville ställa upp mötte vi en svårighet i att deras liv präglades av en så stor instabilitet och ständigt omvälvande händelser att mötet ständigt ställdes in eller sköts upp till en punkt när vi inte längre kunde få kontakt med kvinnorna. Av de kvinnor som jag hade bokat in intervjuer med, och som bodde tillfälligt hos någon bekant, var det ingen som dök upp. En av dem hade blivit utslängd av sin väninnna som inte visste var hon tagit vägen. Till en annan var min enda länk en mobiltelefon, som plötsligt stängdes av pga. av obetalda räkningar. Att det blev en övervikt av kvinnor inom kriminalvården har också sina fördelar eftersom flera av dem inte bott på en institution för bostadslösa utan i det längsta sökt lösa sina boendeproblem genom att bo hos bekanta - vilket är en grupp som annars är ganska svår att få tag i. De som tidigare bott i träningslägenheter eller annan form av institution kunde tala ganska fritt om denna tid eftersom de inte behövde känna en risk att förlora detta boende.

Huvudfokus under intervjuerna låg på deras upplevelser av bostadslöshet och ut- 
anförskap - ett tema som vi sökte närma oss genom att tala om kvinnornas relation till myndigheter, familj, män, kvinnliga vänner och deras upplevelser av att röra sig i det offentliga rummet. Intervjuerna var strukturerade utifrån teman om överlevnadsstrategier, vardagsvillkor, betydelsen av hem, hemlöshet och utanförskap. Den första frågan som ställdes till alla kvinnor var att de själva skulle rekonstruera en berättelse kring första gången de blev utan bostad och de händelser som följde på detta. Syftet med detta var att få en bild av hur kvinnorna själva talade om dessa händelser och utifrån deras egen berättelse sedan gå vidare med de mer temainriktade frågorna. En fråga som har ställts till alla kvinnor är hur de ser på vad ett hem är.

Bland de sju kvinnor jag träffat var det två stycken som hade barn - båda barnen var placerade på familjehem. En kvinna hade levt tillsammans med en man och hans två barn men efter en skilsmässa förvägrats kontakten med barnen. Alla kvinnorna hade erfarit minst en period av bostadslöshet och några hade för kortare eller längre tid tvingats sova utomhus. Dessa perioder hade oftast avbrutits genom att de kunnat sova tillfälligt hos en manlig bekant. Endast en av kvinnorna hade utbildning och hade haft ett fast och relativt väl betalt arbete innan hon blev bostadslös. ${ }^{2}$

2 Av etiska skäl har jag valt att inte göra en individuell beskrivning av kvinnorna då dessa skulle kunna identifieras. Alla namn i artikel är fingerade.

\section{Utanförskapets dimensioner}

Begreppet utanförskap används of ta tillsammans med närbesläktade termer som marginalisering och exklusion även om det finns betydelsefulla skillnader mellan dem. Gemensamt för dessa är dock att de är rumsliga metaforer som refererar till att de som är utanför, exkluderade eller marginaliserade, har en viss lokalisering i förhållande till ett antaget centrum. En person eller en grupp kan mycket konkret befinna sig utanför detta centrum - genom till exempel olika former av gränskontroll som inte tillåter dessa att komma in. Flyktingar som inte tillåts att passera ett lands gränser är ett exempel på detta. De kringdrivande som under medeltiden inte fick passera genom en stads murar är ett annat exempel. Men en grupp eller en person kan också stå utanför i en mer metaforisk bemärkelse, vilket kan innebära att de står utanför arbetsmarknaden, bostadsmarknaden etc. Denna typ av utanförskap refereras ofta till i politiska sammanhang som att personen är exkluderad eller marginaliserad i förhållande till arbets- och bostadsmarknaden. Problemet när exklusion används i denna metaforiska bemärkelse är att det lätt kan bli värdeladdat. Exklusion får då inte bara betydelsen att man inte har ett arbete eller en bostad utan blir också en lokalisering i förhållande till vad som anses normalt, vad som tillhör gemenskapen och dess kulturella värderingar. Den som står utanför denna gemenskap representerar då någon som har ett avvikande beteende, som inte följer de regler som majoriteten tar för givna, vilket ofta leder till att personen får en stigmatiserad identitet. Socialpsykologen Ervin Goffman menar i sin bok Stigma. 
Den avvikandes roll och identitet att i dess ursprungliga betydelse betecknade stigma ett kroppslig tecken, som skars eller brändes in för att varna allmänheten för stigmats bärare på offentliga platser (Goffman 1968:11). De stigmatiserade var alla socialt utstötta personer - brottslingar eller förrädare - och stigmatiseringen var således både ett straff och ett varningsmärke. Idag, hävdar Goffman, har det dock skett en förskjutning i hur begreppet används och istället för att beteckna ett kroppsligt tecken är stigma mer relaterat till egenskaper hos en individ. Det som är utmärkande för stigmatiseringen är att den reducerar en individ från att vara en "hel" och komplex person till att bli den egenskap eller det tillstånd han eller hon har blivit stigmatiserad för. Hemlösa är en av de grupper som länge har stigmatiserats av de omgivande samhällena, ansedda som annorlunda och som några som inte riktigt passar in (Hopper 1991). Det paradoxala i det avvikande i hemlösas situation är att det inte är deras beteende i första hand som gör dem till avvikande utan vad de saknar - nämligen ett hem. En brist som sedan kan leda till handlingar som bryter mot våra vardagliga konventioner (sova och äta på gatan, kriminella handlingar, användande av droger etc).

Den traditionella bilden av den hemlöse är också bilden av någon som inte passar in som faller utanför ramarna. Det är bilden av någon som är smutsig, sover på gatan, ofta psykiskt sjuk eller drogpåverkad, vilket gör honom (för den vanligaste bilden är av en man) oberäknelig. Genom historien har hemlösa setts och behandlats som främlingar i samhällets utkanter. Främlingar som ömsom har setts som ett hot mot den sam- hälleliga ordningen och ömsom, kanske just för att de upplevs som ett moraliskt hot, som lockande och fascinerande. Hemlösa kan sägas ha fått representera och även förkroppsliga smutsen i samhället, samhällets slaggprodukter. De inte bara ses som ett störande moment för det politiska ordningsskapandet - de ses också som störande rent kroppsligt genom att de inte alltid beter sig på det ordnade sätt som det förväntas av människor i offentliga miljöer. Sociologen David Sibley menar att smuts ofta används som själva symbolen för utanförskap, för det som inte passar in:

"Dirt (...) is matter out of place. Similary, the boundaries of society are continually redrawn to distinguish between those who belong and those who, because of some perceived cultural difference, are deemed to be out of place. The analogy with dirt goes beyond this, however. In order to legitimate their exclusion, people who are defined as ıtherı, or residual, beyond the boundaries of the acceptable, are commonly represented as less than human. In the imagery of rejection, they merge with the non-human world.«(Sibley 1992:107).

Hemlöshetsforskaren Talmadge Wright skriver att den som inte har ett hem är nout of place« och ses därför lätt som någon som också är nout of control" och därmed hotfull (Wright 1997). Att hemlösa har setts och ses som annorlunda, som några som står utanför samhället, har lett till en mängd olika strategier för att få kontrollera dem eller för att få dem att försvinna - om inte i realiteten så åtminstone att få dem bortom synhåll. Eftersom hemmet kan förstås som den plats där vi kan känna oss trygga och skyddade från den osäkerhet som finns i samhället blir hemlösa också lätt föremål för rädsla 
då de blir en symbol för den yttersta osäkerheten (Marris 1990: 13-14). Osäkerheten av att inte höra hemma någonstans. Även deras existens är osäker eftersom deras antal är svårberäkneligt. Det är inte heller någon som egentligen behöver ta något ansvar för dem. Hemlöshet är en förtätad symbol för det absoluta utanförskapet.

Vid sammankopplingen av exklusion och utanförskap döljs ofta det faktum att de grupper som vanligen refereras till som exkluderade och utanför samhället oftast i allra högsta grad befinner sig innanför, i bemärkelsen innanför samhällets kontroll. Detta gäller även för hemlösa som inte på något enkelt sätt är utanför samhället. Snarare är det så att detta är en grupp som genom sin blotta existens ifrågasätter den traditionella uppdelningen innanför/utanför, privat/offentligt genom att de tvingas leva sina liv $i$ offentligheten. Det är en grupp som inte kan gå hem och stänga dörren om sig utan tvingas äta och sova på platser där de hela tiden kan observeras. De som är hemlösa kan sägas leva $i$ en paradoxal situation genom att de befinner sig både innanför och utanför samhället samtidigt. Det utanförskap som hemlösa kan uppleva är alltså präglat av en djup motsägelse - av att känna sig utanför samtidigt som de upplever sig övervakade och kontrollerade. Utanförskapet är just en erfarenhet av att bli stämplad - som annorlunda i förhållande till dem som antas befinna sig inne i samhället. Deras utanförskap är därför inte bara en fråga om bostäder och bidrag, utan berör i allra högsta grad frågor om vem man är, hur man blir definierad och vad dessa definitioner betyder för hur man sedan ser på sig själv och omgivningen. Våra berättelser om oss själva, vilka vi är, var vi kommer ifrån, vad vi vill med våra liv både uttrycker och formar våra självbilder. Dessa livsberättelser skapas hela tiden i relation till omgivningen och andra människors förhållningssätt till en själv. Den som är hemlös upplever ofta att han eller hon har en stigmatiserad identitet - det vill säga att vara hemlös leder till att bli stämplad som ett socialt problem, som en avvikare (Carlen 1996, Golden 1992). Flera hemlöshetsforskare menar att den stigmatiserade identiteten som hemlös drabbar kvinnor på ett annat symboliskt sätt än vad det gör för de hemlösa männen eftersom kvinnor i högre grad historiskt har knutits till hem och familj (Watson \& Austerberry 1986, Hanström 1991, Golden 1992, Passaro 1996).

I boken The Women Outside undersöker Stephanie Golden olika föreställningar om hemlösa kvinnor och hur kvinnorna själva förhåller sig till dessa. Hon menar att kvinnors hemlöshet och utanförskap upplevs som mer hotfullt och mystiskt eftersom de inte kan kategoriseras. Genom att kvinnor så länge definierats i förhållande till familjen framstår den ensamma hemlösa kvinnan som en anomali som väcker obehag. I boken undersöker Golden olika populärkulturella föreställningar om den hemlösa kvinnan och finner att dessa innehåller starka mytiska och sexuella element, med en blandning av stark fascination och rädsla. Hemlösa kvinnor, menar hon, ses som dubbelt utanför samhället - både i termer av att de inte har något hem och arbete och genom att de bryter mot den traditionella könsrollen som kvinna.

Bilderna och föreställningarna kring hemlöshet och hemlösa kvinnor är många 
och i sin analys av stigmatisering lyfter Goffman (1968) fram betydelsen av att den som är stigmatiserad har att förhålla sig till en offentlig berättelse, som bland annat uttrycks i media och populärkultur, om vem och hur man är. Det medför att ungdomar eller kvinnor som blir utan bostad redan har en föreställning kring hemlöshetsproblematiken vilket också gör att det inte är ovanligt att de - trots att de inte har en bostad och tvingas sova på gatan - inte ser sig som hemlösa (Watson \& Austerberry 1986, Hutson \& Liddiard 1994, Carlen 1996). De är därför i någon bemärkelse också både innanför och utanför hemlösheten genom att de upplever att de inte har något hem samtidigt som de inte identifierar sig med bilden av den hemlöse. Upplevelsen av att vara både innanför och utanför och egentligen inte känna någon stark tillhörighet leder till vad jag kallar för ett motsägelsefullt utanförskap.

\section{"Livet där ute» - berättelser om vardagens villkor}

I artikeln "Det sociala misslyckandet som berättelse» menar Lars-Christer Hydén att myndigheters utredningar av händelser i människors liv kan ses som institutionella berättelser, det vill säga »berättelser, ensidigt producerade av en eller flera myndighetsföreträdare, och som handlar om en eller flera medborgare.«(Hydén 1995:195). Att tillhöra en viss kategori människor - i detta fallet de bostadslösa - är att bli del av en berättelse kring varför man blivit utan bostad, om vilka problem man har och varför just man själv har hamnat i denna situation (t.ex. psykosociala eller kulturella för- klaringar). Dessa berättelser skänker legitimitet och mening åt myndigheternas föreslagna åtgärder av de utredda klienterna. Men dessa berättelser blir också del av de ut redda individernas självbild och deras sätt att berätta sina egna liv. Det utanförskap som den bostadslösa kvinnan upplever är därför delvis kopplat till att hon redan har blivit stämplad som utanför - som någon som måste återanpassas till samhället. Hon har att förhålla sig till en redan färdig bild av henne - en bild som säger att hon avviker från samhällets normer och sakta måste slussas in igen. Detta behöver dock inte innebära att bostadslösa kvinnor helt antar den bild av dem som myndigheterna ger ibland gör de motstånd mot den eller förhåller sig ironiskt till den - men de måste alltid inta ett förhållningssätt.

De kvinnor som jag har träffat har alla haft mycket kontakter med myndigheter och de är väl förtrogna med de institutionella berättelserna om varför en individ blir bostadslös och hur det är möjligt att komma ur detta tillstånd. Det märks när jag intervjuar dem framförallt genom uttryck som "myndigheterna har förlorat förtroendet för mig» eller att de säger om sig själva att de är "socialt missanpassade", "inte kan klara ett eget boende» och måste »återslussas in $\mathrm{i}$ samhället igen«. Deras egna berättelser om sina liv kan ses som en slags förhandling mellan vad de har fått lära sig om sin situation i kontakterna med myndigheterna, den bild de via populärkultur och media har av hemlöshet och hur de själva direkt upplever sin situation.

Det gemensamma för de kvinnor jag intervjuade är att de lever under vad man kan kalla för instabila boendeförhållanden. Det- 
ta innebär att de pendlar mellan att bo på olika typer av institutioner eller jourboenden, några tillfälliga nätter hos någon vän och periodvis utan någonstans alls att bo. Deras vardag är därför i hög grad präglad av kontakter med myndigheter och beroende av att vänner tillfälligt kan upplåta plats på soffan. I en bemärkelse kan man därför säga att en stor del av deras tid går åt till att mycket konkret försöka »komma in" eller »stanna inne» på det ställe där de tillfälligt bor.

Mia har varit bostadslös i två olika omgångar - en gång när hon var tjugotre och en gång tio år senare. Båda gångerna levde hon utan egen bostad under närmare ett år. Så här beskriver hon sin vardag:

Jag pendlade från soffa till soffa liksom. Aldrig något fast eller något eget eller något sådant där. Jag bodde i en kappsäck då och hade bara kläderna jag stod $\mathrm{i}$.

CE - Blev du utslängd från en del av de ställen du bodde på?

- Ja, det var ju många gånger då för att man kanske klev någon på tårna. Eller att dom helt enkelt tröttnade på en. Och då bodde jag i källare, vindsförråd, trappuppgångar.

Den vardag som Mia beskriver här är karakteristisk för hur vardagen som bostadslös kan se ut. Att leva under dessa villkor, att inte ha en fast punkt i tillvaron kan ibland också leda till att dessa kvinnor upplever ett starkt utanförskap - att dörrarna är stängda för dem, i en mycket konkret bemärkelse och att de är stämplade som utslagna och som sociala problem. Men även om dörrarna är stängda för dem och de »längtar in« i vissa situationer, så upplever de också i andra situationer, att de är winne» och kontrol- lerade utan möjlighet att stänga omvärlden ute. De kvinnor som jag har mött och deras berättelser om sina liv och deras egen självbild är i hög grad berättelser om hur de skall hantera de motsägelser som de upplever över att vara både innanför och utanför samtidigt.

\section{Innanför men ändå utanför - ute men ändå inne}

\section{Skyldigheter och rättigheter}

Ett av de teman som återkommer i flera intervjuer är konflikten mellan rättighet och skyldighet. Denna konflikt skulle man kunna karakterisera som att kvinnorna upplever att de befinner sig innanför samhällets kontroll, genom att det ständigt krävs att de uppfyller sina skyldigheter, samtidigt som de upplever att de står utanför då de känner sig såväl maktlösa som rättslösa. Har man förlorat sin bostad, har stora skulder och saknar arbete så är de sociala rättigheterna knutna till att man först måste uppfylla ett antal skyldigheter gentemot stat och myndigheter. Skyldigheterna kommer således före uppfyllandet av deras rättigheter. Denna situation resulterar ofta i att de upplever sig oerhört maktlösa. När jag frågar Mia om utanförskap och behandling från myndigheterna svarar hon:

\footnotetext{
Utanför.. Jag kände mig så... Dom hade en sådan makt i sina händer och som dom missbrukade $i$ sin tur. Vad skall man säga. Dom var Gud. Och det var ju någonting som man bara får finna sig i alltså. För den lilla människan kan inte göra någonting åt den där stora Guden. Och dom bollar med en precis som dom själva vill. Jag tog det väldigt personligt. (...) Och jag vet att dom är likadana mot andra människor också. Och
} 
jag tror att dom tar det lika personligt dom med. För varje människa måste ha en chans och inte bara en utan många chanser.

Har man väl en gång hamnat utanför den reguljära bostadsmarknaden - genom att man har blivit vräkt för att man har haft ett störande beteende eller inte kunnat betala hyran - är man i princip hänvisad till de sociala myndigheternas omsorg. För att få en lägenhet eller ett rum måste man acceptera en del av de krav som myndigheterna ställer på en. Den som inte vill eller kan uppfylla dessa krav kan inte heller förvänta sig att få sina önskningar uppfyllda. För att förtjäna hjälpen måste de visa vilja till förändring, vara motiverade eller visa "sjukdomsinsikt». Att få hjälp är därför inte en självklarhet. Mia beskriver hennes kamp om att få sina rättigheter tillgodosedda så här:

Och jag sa det till dom...ratt jag har rätt att ha någonstans att bo. Om så bara ett rum med utedass eller vad sjutton som helstu. »Det finns ingenting som heter såı fick jag till svar. Dom är väldigt snabba med att upplysa en med vad det är för skyldigheter man har men aldrig vilka rättigheter man har. Om man skulle upplysa dom om att jag har rätt till det och det så får man till svar att du har inte rätt till någonting.

Ofta beskrivs relationen till myndigheterna som en kamp - en kamp om att göra sin röst hörd och få sina rättigheter tillgodosedda. Flera upplever också att myndigheterna ställer krav på dem som inte de kan leva upp till. Anna har varit utan bostad under ett år när jag träffar henne och hon uttrycker det så här:

För jag menar att allting är en ond cirkel för om du inte har något boende så blir du kriminell eller om du inte har ekonomi eller så heller va. Det ena ger det andra - det är en jävla dubbelmoral alltihop. „Fixar du det här - visa att du kan - bli drogfri !! visst gå och pissa en eller tre månader innan du typ får hiälp med pengar och sedan efter det så kan du få bostad. Under tiden står man på gatan... det funkar inte. Och sedan är det ju så... att för att få pengar måste du bli kriminell och för att bli kriminell måste du droga va. Det är ju så. Och drogar man får man inte bostad. (...) Så att stå och jiddra om att dom (myndighetspersonerna, min anm.) vet precis hur jag har det. I helvete heller att dom vet... i så fall hade dom inte betett sig så.

\section{Svårigheten med livet "där inne"}

De flesta av de kvinnor som blir utan bostad står ofta utan både arbete och egna pengar. Flera har också stora skulder. Vissa av kvinnorna börjar använda droger vilket leder dem in i ett liv som är oerhört svårt att ta sig ur. Att komma ur hemlösheten är därför inte så enkelt, menar Anna, och svårare blir det ju längre tiden går eftersom hon börjar lära sig leva och hantera vardagen utan bostad. Så även om hon betonar att hon verkligen längtar efter ett hem är hon rädd för vad det kommer att innebära.

Om man har levt så är det ju svårt att ta sig tillbaka. Du får ju lämna allting, allting får du ju lämna liksom och det...allting verkar ju skitenkelt eller så men det är ju inte så jävla enkelt. Man vet ju vad man har men inte vad man får. Det är ju så - ja det är svårt. (...) Men visst fan är det jobbigt...Det är ett jävla liv att leva för man kan aldrig slappna av eller så. Du kan ju inte gå och lägga dig när du vill eller gå upp när du vill.

Den ambivalens som Anna uttrycker är av stor betydelse. Att både längta efter ett eget hem och vara rädd för vad det livet kommer 
att innebära. Hon talar om allt ansvar som följer med ett hem - att bevisa för myndigheterna att hon kan sköta sitt liv och inte tappa kontrollen. Vägen från att vara helt utan bostad till att verkligen få ett förstahandskontrakt är lång och beskrivs ofta av myndigheterna som en stege - från hemlöshet till härbärgen, träningslägenhet, övergångsbostad och slutligen ett kontrakt. Missköter man sig på en nivå riskerar man att åka ned ett steg. Många hemlösa kommer aldrig till det översta trappsteget utan tillbringar stor tid med att klättra upp och ramla ned igen (Sahlin 1998). Att leva under dessa omständigheter under lång tid där de får höra att de inte klarar eget boende och ännu inte är mogna för att få ett riktigt kontrakt påverkar givetvis självbilden.

Några av kvinnorna upplever också den ständiga kontrollen som en djup kränkning, vilket gör att de blir ovilliga att ställa upp på de krav som ställs på dem under den tid då de skall träna sig att sköta en lägenhet. Susanne blev av med sin lägenhet när hon var tjugonio och har sedan dess pendlat mellan institutioner och tillfälliga boende hos bekanta. Att någon skall ha nyckel till hennes rum och kunna kontrollera vad hon gör och vem hon umgås med upplever hon som en kränkning av hennes privatliv.

Som det är här är det som är mitt, mitt rum och när dom går in där och gör visitation... Det har dom ju rätt till men det är ju det som är mitt det är ju vad jag har? Jag menar att om jag har en väninna och vi sitter och ser på en film så får jag inte ha besök efter tio. Jag får inte släppa in någon som är påverkad men man kan ju inte springa ifrån knarket och det kan ju komma någon som är påverkad men uppför sig helt okej. Skall jag ta urinprov på dom då?
Susanne beskriver kraven och förväntningarna på henne från såväl myndigheter som anhöriga som en börda. En börda som hon liknar vid en ryggsäck som är för tung att bära. Krav och förhoppningar från andra om att hon skall förändra sitt liv är inget stöd, menar hon - tvärtom upplever hon att det hindrar henne från att resa sig igen.

Att inte längre ses som ett problem och en belastning är för Mia centralt för att hon inte längre skall känna sig stigmatiserad utan som en del av samhället. Så här svarar hon på frågan om hon fortfarande, nu när hon har fått en lägenhet, känner sig utanför samhället:

\begin{abstract}
Ja, jag känner fortfarande att det är jag och dom. Och det har inte bara med bostadsfrågan att göra utan det är ju annat också. Det är först när man får ett arbete också och man känner att man drar sitt strå till stacken. Då kan man faktiskt känna att ıjagär en av dom ocksåu.
\end{abstract}

För Mia har tiden som hemlös satt djupa spår och hon är fortfarande rädd för att bli stämplad som ett socialt problem vilket har skapat en osäkerhet hos henne i relation till omgivningen.

Så länge jag befinner mig i min lägenhet då känner jag att jag är hemma. Men så fort jag går utanför dörren och skall gå ner i källaren - t.ex. till tvättstugan - då känner jag en osäkerhet om att jag skall trampa någon på tårna så att grannarna skall börja klaga och...Ja och jag menar på att jag kanske är störande och de vill bli av med mig....Ibland vågar jag ju knappt hosta. Så på så vis har det skapat en väldig osäkerhet hos mig.

Hennes erfarenheter från tiden som hemlös har gjort att hon fortfarande känner sig 
stämplad och hon känner inte längre någon tillit till vare sig grannar eller till myndigheterna. Då hon ännu inte har fått något arbete måste hon fortsätta att söka sig till socialen för hjälp vilket hon kommenterar med orden:

Men jag tror inte på dom mer. Jag litar inte på dom för fem öre. Jag går dit för att jag är nödgad att gå dit.

Att ha skulder, inte ha ett arbete och ingen bostad är alla faktorer som bidrar till att dessa kvinnor upplever att de inte tillhör samhället, att de inte är önskvärda utan endast ses som en belastning - ett socialt problem. Eva har inte haft någon fast bostad sedan hon rymde från sina föräldrar som tonåring och har idag skulder som hon inte kan betala. Även hennes berättelse är präglad av att hon känner sig stämplad - som »en sån'däru.

I dagens samhälle kan ju jag inte söka lägenhet, jag har ju skulder va. Det är ingen som vill ha en sådan.

\section{Utanför lagen - innanför väggarna}

För den som saknar bostad eller arbete och har stora skulder kan kriminalitet fylla flera behov - att få pengar och att tillkalla uppmärksamhet. Mia säger:

Att det var tack vare den tiden (som bostadslös, min anmärkning) som jag sitter här (på anstalt, min anm.) idag t.ex. För jag gjorde ju saker och ting liksom för att få socialen till att uppmärksamma att - „Här är jag ! Jag finns till !! Ge mig tak över huvudet!!» Jag menar det jag gjorde, gjorde jag för två år sedan och sitter här nu. $\mathrm{Nu}$ har jag ju lägenhet va. $\mathrm{Nu}$ spelar det ju...nu hade det ju kvittat liksom. Då gjorde jag det bara för att få någonstans att ta vägen. Så panik var det alltså. Det var ju då snöstormen var också... ${ }^{3}$

När kvinnorna anhålls utreds deras situation och möjligheterna till att få hjälp ökar paradoxalt nog. Som anhållna får de också tak över huvudet och mat vilket kan vara nog så behövligt efter en tid på gatan. Efter ett år utan bostad säger Anna:

Det har ju varit många gånger som man inte har haft någonting - ja - man har sovit i skyddsrum och så. Eller så kan du inte komma in någonstans och då har man ju rantat runt hela natten. Så nu var det rätt gott att ıåka in« vet du. Speciellt nu när det börjar att bli kallt.

Den kriminella verksamheten blir en del av det motsägelsefulla i kvinnornas utanförskap. För att få »komma in « och få tak över huvudet så överskrider de samhällets lagarde ställer sig "utanför « reglerna om vad man fär och inte fär göra.

Men kriminaliteten kan också bli en fråga om överlevnad, ett sätt att skaffa en inkomst. För Susanne blev kriminaliteten ett lätt sätt att komma över pengar när socialen inte längre ville ställa upp med bidrag.

Så socialen slutade att betala både uppehälle och hyra. Det var då jag började med min kriminella verksamhet - jag hade inget val. Det var bara att gå på gatan eller att göra något kriminellt för att försörja mig. Dom (socialtjänsten, min anm.) hade inget förtroende kvar för mig så dom bara stannade upp allt vilket tvingade mig in i kriminaliteten kan man säga.

3 Snöstormen som Mia refererar till ägde rum 17 november 1995 och lamslog bland annat Göteborg för en dag. 
För att få hjälp måste Susanne vinna tillbaka myndigheternas förtroende - visa att hon förtjänar samhällets hjälp igen. Den bild som myndigheterna förmedlar till dessa kvinnor av dem själva är att de kan få hjälp att komma in i samhället om de bara visar att myndigheten kan ha förtroende för dem. Indirekt förmedlas därför också en bild av att de har sig själva att skylla, att de inte skulle behöva vara hemlösa om de bara skötte sina liv. Flera kvinnor uttrycker också att de känner att deras hemlöshet är deras eget fel samtidigt som de också berättar om maktlöshet, kränkande av deras integritet och samhällets dubbelmoral.

Berättelserna om vardagens villkor, om "livet där ute«, är lika mycket berättelser om "livet där inne« och kan ses som olika försök att ge mening åt det motsägelsefulla utanförskap som de upplever.

\section{Synlig men ändå osynlig - hemlös i det offentliga rummet}

En betydelsefull aspekt av interaktionen mellan människor är skapandet av olika sociala rum. Stadens centrum är ett sådant socialt rum där människor rör sig för att ta sig mellan olika platser, för att träffas, uträtta ärenden eller bara flanera. När Goffman diskuterar de sociala rummen gör han en distinktion mellan de främre och de bakre regionerna (Goffman 1974). De främre regionerna syftar på de rum som är offentliga - där individen hela tiden kan bli iakttagen av andra människor och därför styr sitt beteende så att hon kan kontrollera vilka intryck hon gör på andra människor. Det är i dessa regioner som människor spelar olika roller och visar upp sina yttre fasader. De bakre regionerna däremot syftar på de rum där individen kan vara sig själv och inte behöver upprätthålla en fasad, utan kan slappna av och göra allt det som hon aldrig skulle drömma om att göra inför andra människors blickar. För den som inte har något hem har skillnaden mellan dessa olika rum upphävts - den hemlösa tvingas med andra ord att ständigt leva sitt liv i andra människors främre regioner - där hon riskerar att bli sedd i situationer som hon helst hade dold för okända människors blickar. Det är ett av skälen till att hemlösa ofta orsakar en reaktion hos de människor som passerar dem eftersom de bryter mot de vardagliga konventionerna $i$ hur vi bör bete oss $i$ offentliga miljöer. Men hemlösa kan också ge upphov till en reaktion för att vi tvingas att se att det finns människor i vårt samhälle som inte har någonstans att ta vägen - som ingen tar ansvar för.

Den hemlöse förkroppsligar på ett paradoxalt sätt flera av de etiska, politiska och psykologiska dilemman som finns i vårt samhälle. Deras närvaro ställer frågor om hur samhället skall organiseras och vilket ansvar vi har för våra medmänniskor på sin spets. Psykologiskt skapar de ett dilemma för att vi inte kan undvika deras närvaro och vilken kan skapa en rad motstridiga känslor hos oss.

Det motsägelsefulla utanförskap som hemlösa kan uppleva är intimt förknippat med blicken - med att bli sedd och att inte bli sedd. De som inte kan dölja sin hemlöshet är ofta väl medvetna om att de orsakar en reaktion hos andra människor - att de inte går obemärkta förbi. Att bli sedd som hemlös kan upplevas som att inte bli sedd som indi- 
vid. De människor som passerar ser inte personen utan en kategori.

\section{Normalitet och osynlighet}

Att bli bemött med rädsla eller att ens hemlöshet blir ifrågasatt är något som kvinnorna jag intervjuat har varit med om. Detta förstärker också deras erfarenhet av utanförskap. Anna säger så här:

Och det är det som är så jävla lustigt för många normala människor - dom tror inte att det finns bostadslösa eller så. (...) Och vi bara flabbar eller så va..och jag menar - att det är jävligt många. (...) För alla normala människor dom kan absolut inte förstå för det är ju så långt i från deras verklighet. I allmänhet tror jag inte att folk kan tänka sig....vad som helst kan hända men boendet det har dom ju alltid för det är ju tryggheten liksom. Och jag tror aldrig att en normal människa kan tänka sig att det händer mig. Absolut inte. För det har dom ju alltid haft - det är ju självklarheter. Men det är inte så jävla självklart.

"Normala människor» är för Anna sådana som har en bostad och tillhör den samhälleliga gemenskapen. När hon talar om sig själv och sina vänner särskiljer hon hela tiden dem från normaliteten, genom att inte ha ett hem avviker de och blir stämplade som onormala. Annas berättelse tyder dock på att uppdelningen av normala människor och de andra - de bostadslösa - inte är hennes egen. Snarare ser hon att hon och hennes vänner också är vanliga normala människor. Däremot är det en åtskillnad som hon har erfarit att andra människor gör - att de ser på henne som om hon inte vore normal. Hon tror också att de "normala människorna» skulle ta avstånd från henne om de fick veta att hon inte har någonstans att bo.
Om jag skulle sitta och snacka med någon - en normal människa - och sedan säga att jag är bostadslös så till 50 procent så tror jag inte att dom pratar med mig igen. För givetvis det ena ger ju det andra. "- Jaha du är utan bostad." Men det är ju inte så konstigt. Jag skiter egentligen i vad andra tycker - det kan inte jag springa runt och må dåligt för. Det är ju bara en brist på förståelse. Det är bara någonting dom inte kan ta på och dom är rädda för det.

Upprepade gånger talar hon om att det är en sjuk värld som de lever i, att hennes och hennes vänners sätt att hantera vardagen och deras upplevelser av att inte ha någonstans att ta vägen måste te sig som oerhört märkliga från en "normalı människas perspektiv. Ett exempel på vad hon ser som en onormal reaktion är att hon uppskattar att bli inlåst på häktet - att få ett låst rum där hon kan få vara ifred och ha en säng att sova i. Att bli inlåst är enda möjligheten för Anna att fullständig kunna slappna av - ett stängt rum som hon vet att hon kan vara ensam i. Ändå tror hon att om de "normala» människorna verkligen såg henne och hennes vänner så skulle de behandla dem på ett annat sätt.

Om dom ser att vi är vanliga människor vi med - att vi också faktiskt kan sköta oss och att det inte är så att vi slafsar ned och smittar omgivningen. När dom ser det, att även vi kan hålla rent och snyggt, att vi också fungerar va - så tror jag faktiskt att dom blir humana och visar lite empati. Det är ju vad det handlar om, det är bara rädsla, att folk dömer och så dömer dom bara när dom inte vet vad det handlar om. Om dom inte vill ha mig, alltså i trapphus eller i dusch och källare, om dom kommer ned och får syn på nån, ja du vet. Jag har full förståelse för att dom blir förbannade och börjar gapa och skrika eller ber en att fara åt helvete - du vet. Det är ju deras-det får man respektera då. 
Anna pekar på den rädsla som människor kan känna när de kommer i kontakt med hemlösa - en rädsla över något som de inte känner till och inte kan kontrollera. Ändå respekterar hon deras rädsla och ilska eftersom de har något som inte hon har - nämligen ett hem och därmed en självklar rätt till de utrymmen som kan utgöra ett nattligt skydd för den som är hemlös.

Anna och de andra kvinnor som jag har intervjuat har alla betonat att de inte vill bli sedda som hemlösa när de rör sig i de offentliga rummen. Detta tar sig uttryck i att de utvecklar olika strategier för att dölja sin hemlöshet när det är möjligt - vilket gör att deras hemlöshet $i$ en bemärkelse är osynlig. Anna beskriver det så här:

För det är vi jävligt noga med (att duscha, min anm.). Det tror jag faktiskt att vi är mer noga med om man tänker på hygien och så va. För många kanske förknippar det här att man är bo stadslös va att då är du en jävla..ja du vet. håliga jeans och skiten och du vet så va. Men det är faktiskt tvärtom. Man har ju alltid nya kläder. Och man kan ju inte tvätta så det blir till att stjäla nytt. (...) Det är vår grej liksom..det är det enda vi kan göra. Så det är absolut ingen som kan möta mig på stan och tänka aha hon har ingen bostad. Det är enda gången som jag kan smälta in i mängden.

Annas sätt att undvika den stigmatiserade identiteten som hemlös och känna att hon tillhör de "normalas skara", är helt enkelt att se till att hon inte svarar mot den stereotypa bilden av den hemlösa. Detta innebär också en lättnad för henne - när hon rör sig i det offentliga rummet är det ingen som kan se på henne att hon inte har ett hem, hon behöver inte känna sig utpekad och annorlunda utan kan för omväxlings skull känna sig som en del av mängden. Även Sofia som har varit hemlös i olika omgångar betonar vikten av att inte bli sedd som hemlös:

\begin{abstract}
Man kan ju inte hålla sig ren om man är ute och ränner hela tiden...det har hänt att jag har gått till campingen och duschat. ( ... ) Det är viktigt för mig att kunna gå ut fräsch - annars känner man sig verkligen utanför samhället. Bara att kunna duscha varje dag det är ett måste. Det vet du själv. Särskilt som tjej - killar är kanske inte lika noga. Men tjejer är ju det.
\end{abstract}

Och hon säger:

Om vi säger så här - jag klär mig snyggt, jag kan gå inne bland folk och så och jag har ingenting att skämmas för.

Att se snygg ut och att kunna känna sig fräsch är viktigt för dessa kvinnors självkänsla. Smutsen och de trasiga kläderna är för dem symboler för hemlöshet och så länge de kan hålla sig rena och fräscha så känner de sig inte hemlösa - även om de samtidigt mycket starkt upplever att de inte har något hem.

\section{Hemmet som symbol}

I en undersökning av engelska arbetarklasskvinnor fann Beverly Skegg (1997) att de associerade begreppet arbetarklass med smuts, ohövlighet och brutalitet, vilket ledde till att de lade ned stor möda på att inte se ut som om de kom från arbetarklass. De ansåg att de bemöttes med mer respekt om deras klassposition inte avslöjades. Att ha ett fint hem var en av de faktorer som kvinnorna i Skeggs studie fann ytterst betydelsefullt för att vinna denna respekt. Att inte ha ett hem innebär inte bara att man inte har 
någonstans att dra sig tillbaka, att leva sitt privatliv, utan också att man inte kan uttrycka sin identitet genom hemmet. Hemmet fungerar med andra ord som en symbol för status och identitetsskapande. ${ }^{4}$ För de kvinnor som inte har något hem blir utseendet och kroppen den sista och enda uttrycksmedlet. För att upprepa vad Anna säger behovet av att ha rena och nya kläder; „Det är vår grej liksom....det är det enda vi kan göra."

Även om det är betydelsefullt för kvinnor utan hem att uttrycka sig genom sin kropp och sina kläder och därigenom också dölja sin situation, så drabbar hemlösheten kvinnor på ett annat symboliskt sätt än vad det gör för de hemlösa männen. Stephanie Golden menar i sin undersökning av föreställningar kring den hemlösa kvinnan att:

... a homeless woman creates discomfort because she cannot be categorized. Women are so entierly defined in terms of whom they belong to that no category exists for a woman without family or home. (Golden 1992:5)

Det ideala hemmet står för trygghet, en stabil familj och hemtrevnad. Denna bild drabbar särskilt kvinnor. Geografen Gillian Rose (Rose 1993:56) menar att idealiseringen av det trygga hemmet är en logisk följd av vad hon kallar för feminiseringen av platsen. Hemmet, hävdar Rose, ses som en konfliktfri plats där kvinnan står som symbol för närheten och tryggheten. Att kvinnor associeras till hemmet och till huslighet gör det

4 Detta tema utvecklas av Abby Peterson i hennes artikel "A locked door. The meaning of home for punitively homeless young women in Sweden.»Kommande. särskilt skamfyllt för kvinnor att inte ha ett hem - speciellt om de dessutom har barn.

Första gången Mia var utan bostad var hon bara tjugotre och hade ännu inte fått barn, medan hon andra gången hade en dotter som blivit omhändertagen av myndigheterna.

Första gången, då skämdes jag väl inte så. Man skämdes för att man var bostadslös, visst gjorde man det men inte alls på samma sätt. Fast nu sista gången, fast man skämdes, ville man göra sin röst hörd. Jag ville skrika ut den maktlöshet som jag kände då - att jag inte kunde göra någonting. Och detta ville jag upplysa så många som möjligt om. Just då. Fast man skämdes. Men det fick man liksom stoppa ned i halsen.

När kvinnorna blev sedda som hemlösa kände de sig både sårbara och utsatta. Det offentliga rummet är för dessa kvinnor en "kritisk miljö» - dvs. en miljö där de inte kan känna sig trygga och där de också riskerar att få sin självkänsla kränkt (Johansson 1997:95). Även om de betonar att de utvecklar strategier för att dölja sin hemlöshet så finns det tillfällen när den inte går att dölja. I synnerhet om nätterna när de måste finna någonstans att sova. Vid sådana tillfällen kommer också skamkänslorna. De skäms över att behöva bli sedda när de sover i någons trapphus eller på en toalett. Anna söker sig ofta till skyddsrum om nätterna för där vet hon att hon får vara ifred och att hon inte heller blir sedd.

Och nu vet jag ställen där jag kan vara som inte många känner till och där jag får vara ifred. För inte fan hade jag gått och lagt mig någonstans där folk trampar på en. Eller som man blir utsatt för...Man vill ju gärna gå och gömma sig då. 
Mia berättar att hon har försökt att få vila i trappuppgångar men blivit ivägkörd.

Då var man ju en slusk. Dom nästan jagade ut en med en sopborste. Nu hör det ju till... (att vara bostadslös, min anm.)

Är man bostadslös, menar Mia, så får man räkna med att människor behandlar en som om man vore en "slusk", något orent som måste »städas bort». Att behandlas på detta vis skapar en djup känsla av utanförskap och en upplevelse av att ha förlorat sitt människovärde.

\section{Skam och stolthet}

Filosofen Gabriel Taylor (1985) menar att skamkänslor härrör från att individen känner sig degraderad, att hon inte bli sedd som den person hon vill vara eller hoppats att hon är. Hon upplever att hon blir exponerad för en annan människas värderande blick, en blick som hon inte kan värja sig emot. Denna blick vänds sedan mot individen själv - hon ser sig själv genom den andra och känner då skam. Att bli sedd som hemlös, som en slusk eller som någon som - med Annas ord - smittar omgivningen, leder till att kvinnorna ser på sig själva med en annan människas blick - och ser då den hemlösa kvinna de inte kan identifiera sig med.

När jag intervjuar Ida så kommer vi in på skammen att inte ha något hem. Ida rymde hemifrån när hon var tolv och levde då utan något hem i tre månader och har sedan dess varit bostadslös i flera omgångar. Hon berättar att hon trots att hon varit utan bostad så länge inte velat söka hjälp på härbärgen för kvinnor. När jag frågar varför svarar hon:
Man blir som man bemöts - och blir man bemött som en bostadslös, utsatt kvinna - så känner jag mig som det. Och även om det är så om man inte lever efter det själv då känns det inte så jävligt.

CE Känns det skamfyllt då ?

Ja det gör de ju. Jag tycker inte att det är något skamligt i utnyttjande- situationen eller i att bli utnyttjad eller att använda sig själv som kvinna för att kunna ha någonstans att ta vägen. Det tycker jag verkligen inte utan det ser jag som en överlevnadsinstinkt. Så god som någon. Men någonstans där så vet jag att det finns en dömande faktori det hela och jag vet att man dömer sig själv. Och det kommer ju automatiskt in i bilden för många kvinnor.

Det är först i mötet med andra människor som Ida känner de dömande blickarna vilket också gör att hon dömer sig själv - och känner skam över sin situation. Och när jag senare frågar henne vad hon tänker på när hon hör ordet hemlös svarar hon snabbt att hon inte tänker på sig själv. Hon vill inte se sig som hemlös även om hon efter en stund säger att hon kan tänka på sig själv som hemlös och då i termer av ett bestående tillstånd.

I en annan kontext så har filosofen och psykologen Frantz Fanon skrivit om den skam och det självhat som den svarte mannen kan känna inför sin egen hudfärg. Fanon betonar att det är först i och med mötet med den vite mannens nedvärderande blick som den svarte mannen inser sin svärta och ser sig själv genom den andres ögon. Han beskriver erfarenheten av att bli uttittad och utpekad:

Mamma, titta på negern, jag är rädd! Rädd! Rädd! Nu började man alltså bli rädd för mig. Jag ville skratta mig halvt fördärvad men kunde inte. (...) Mitt kroppsschema, som nu attackerades från alla håll, föll sönder och ersattes av ett 
rasschema baserat på hudfärg. På tåget handlande det inte längre om en medvetenhet om min egen kropp i tredje person, utan i tredubbel person. På tåget lämnade man mig inte en plats, utan två, tre platser. Det var inte det att jag såg världen i feberhallucinationer. Jag levde i tre personer: jag tog upp plats. (Fanon 1995:109)

Även om Fanon beskriver svartas upplevelse så skildrar han en erfarenhet av att både bli sedd och att inte bli sedd som delas av hemlösa. Att bli lämnad plats, att orsaka rädsla eller ilska, att se att en annan människa inte vill möta ens blick eller ser på en med avsky är en erfarenhet som de kvinnor jag har mött vittnar om. Förnedring och ständiga känslor av skam var en del av vardagen för Mia när hon var bostadslös. Hennes berättelse om tiden utan bostad är en berättelse om hur hon upplevde att hon förlorade sitt människovärde och blev sedd som något som var mindre värt - vilket också påverkade hennes självbild. Hon säger:

Ja som jag kände mig....värdelös...jag var inte någonting. Jag började att bli desperat då också. "Gör någonting hjälp mig!» liksom. Jag hotade med att ställa upp ett tält utanför kommunhuset. Men jag hade ju inte ens ett tält. Jag försökte bygga hyddor ute i skogen och sånt där. Men jag var så väldigt...jag kommer inte ihåg mycket av den tiden heller för att det var...Det är som att man förtränger det...

Och hon fortsätter:

Oftast var det som att man gick runt som en tiggare va. Att man fick...Man sjönk ju väldigt lågt. Man fick göra saker som man aldrig skulle kunna tänka sig att göra liksom - i vanliga fall. Man fick verkligen svälja stoltheten. Den fick man nedkörd $i$ halsen många gånger.
Erfarenheten av att tvingas svälja sin stolthet och stå ut med förödmjukelse är något som återkommer i flera intervjuer. En strategi för att hantera skamkänslorna verkar vara att utveckla ett skydd omkring sitt jag - »ett pansar« som Susanne kallar det. För Susanne blir pansaret det skydd som ett hem kan erbjuda - en privat sfär där ingen får komma in och där hon är skyddad från omgivningens tankar och blickar. Men pansar gentemot omgivningen kan också leda till att man stänger sig själv och sina egna känslor ute. Så här beskriver hon sin längtan efter kärlek och närhet.

\footnotetext{
Men då blir man i en beroendesituation och då blir man svag. Ensam är inte stark - men i kärleken blir man svag. Men det är ju det som är det finaste och det som jag har längtat efter i hela mitt liv och aldrig fått och inte heller vågat tillåta mig själv. Och inte klarat ta emot hjälp eller att någon tycker om mig. Då backar jag när någon kommer för nära. Så jag vågar inte ens känna utan jag stänger av.
}

Psykoanalytikern Léon Wumster (1981) hävdar i sin bok The mask of shame att skammen är intimt förknippad med en brist på kärlek, och att inte bli sedd av den andre. Att inte bli sedd är inte bara att bli respektlöst mött - det är också ett intrång i den personliga integriteten. För att skydda sig mot den andres blick så skapar individen, menar Wurmser, ett skydd omkring sig, en mask. Den som inte har ett hem riskerar ständigt intrång i den personliga integriteten. Det pansar som Susanne talar om blir hennes substitut för ett hem, en låst dörr som hon har kontroll över.

Kvinnor som är hemlösa möts ofta av antaganden om att de är prostituerade eller åt- 
minstone går i säng med en man för att få tak över huvudet. Mia berättar:

Många gånger när man kom in på socialen så hade dom förutfattade meningar om att det var precis som att jag sålde mig. Att jag prostituerade mig på många sätt och vis för att få någonstans att ta vägen men det var det ju inte frågan om och jag blev så förbannad för att dom tror något sådant.

För alla de kvinnor som jag har mött har det varit viktigt att göra det tydligt för mig att de inte har varit prostituerade. De har själva tagit upp ämnet i intervjuerna och noga understrukit att även om de inte har haft något bostad så har det aldrig varit så illa att de har behövt använda sin kropp för att få tak över huvudet. Flera har också sagt som Ida att bara för att man är bostadslös så "måste man förklara att - nej jag är verkligen inte prostituerad». Frågan är känslig och det märks att kvinnorna blir sårade över hur de har blivit bemötta och känner att de måste försvara sig mot sådana antaganden. När jag t.ex. vid ett tillfälle kommer in på frågan om utsatthet, utan avsikt att tala om prostitution, reagerar Sofia med orden:

Nej, aldrig att jag skulle gå hem till någon och lägga mig i sängen, inte på dom premisserna. Aldrig i livet - så är inte jag skapt.

De berättelser som kvinnorna under intervjuerna förmedlade handlar alla om skam och förnedring men också om stolthet och viljan att klara sig och tro på sig själv. Det är berättelser om beroende och utsatthet men också behov av att markera gränser och om en tro på att de kan klara sig själva och att allt kommer att ordna sig. Ett vanligt svar på mina frågor om utsatthet och skam är att man måste lära sig att bli tuff - att klara sig själv. Sofia säger:

Utsatt - ja det är man. Men är man tuff så klarar man det. Men roligt leverne är det ju inte. Man får förlita sig på andra - att dom ställer upp och så. Och det är inte alltid dom kan göra det.

Anna hävdar att för att klara dagen måste man hela tiden intala sig att allt kommer att ordna sig.

\begin{abstract}
Men samtidigt...man pallar inte med att tänka på...man pallar inte med att se klart på situationen för då hade ju alla gått ned sig. Man har ju den filosofin att det ordnar sig. På ett eller annat vis så gör det ju det.
\end{abstract}

Genom att tro på sig själva, att hela tiden intala sig att allt kommer att bli bra och anstränga sig att inte se hemlösa ut kan de tänka att de fortfarande kan, att de har möjlighet att lösa sin situation - att det bara är en tidsfråga. Anna menar att detta är speciellt viktigt för en kvinna eftersom kvinnor är mer utsatta när de står utan bostad. Man måste hela tiden stå för den man är, hävdar hon, annars riskerar man att bli trampad på:

\begin{abstract}
Jag står för mina åsikter - mina tankar - jag vänder inte kappan efter vinden - min åsikter har lika stor vikt som andras. Det handlar om respekt helt och hållet. Men att man är kvinna...folk kanske tror att dom kan köra över en lättare. ( ... ) Jag menar det att som tjej har man två möjligheter - antingen underskattar du dig eller så lyfter du dig själv. Och jag har aldrig underskattat mig själv.
\end{abstract}

Att inte bli sedd som ett offer utan kunna 
vara stolt över sig själv och den man är oerhört viktig för Ida. Det har gjort att hon periodvis har velat förneka att hon är bostadslös - för att hon inte vill bli sedd och bli behandlad som en stackare. Men det senaste året har hon sålt tidningen Situation Stockholm - en tidning som säljs på Stockholms gator av bostadslösa. Samtidigt som hon upplever att det är jobbigt att "visa upp sig" som bostadslös menar hon att hon också kan känna en stolthet - att hon blir någon.

Det sista året så har jag sålt den här tidningen Situation Stockholm och då säger jag att jag är bostadslös och gör en förtjänst på tio kronor. Och det är jävligt jobbigt. (...) Men samtidigt så är det faktiskt någonstans där som det blir en stolthet. Ja och jag känner då att om någon tittar snett på mig så tittar jag snett på dom. Har jag inte den tidningen utan bara sitter någonstans och ser folk så ser jag aldrig dom som vänder sig till mig och hjälper mig. Så har man tidningen så ser man jävligt positivt på dom som kommer och köper tidningen och säger någonting.

\section{Kvinnors hemlöshet och det motsägelsefulla utanförskapet - avslutande diskussion}

Att leva som bostadslös är hårt och det är inte ovanligt att den som har varit bostadslös får men för livet - fysiska eller psykiska. Ida säger:

...leva som bostadslös vare sig man är man eller kvinna - det är fruktansvärt. Det är det. Och någon form av missbruk finns det - man missbrukar sig själv om inte annat. Man går hårt åt sig själv missbrukar sig själv. Blir det inte rus så blir det någon psykisk grej sådär att man kollar upp alla tågtider eller något annat. Det går inte att bara leva $i$ detta - att vara bostadslös. För man blir här och nu i sig själv. För det är det enda man har att ta vägen $i$ - sin egen kroppshydda. Och man far väldigt illa. Och då blir man betraktad som offer och känner sig väldigt hjälplös. Oavsett om man är det eller inte. Men det är man ju. Offer för sig själv offer för situationen och offer för samhället.

Har man inget eget hem så har man inte heller något skydd mot omgivningen. Det enda "hem" man har blir som Ida så mycket riktigt påpekar den egna kroppshyddan och denna skyddar vare sig mot kyla, mot fysiskt våld eller mot omgivningens blickar. Det skydd som de kan utveckla är det pansar som Susanne talade om - ett pansar som kan slå tillbaka mot dem själv t.ex. genom att de får svårt att ta emot hjälp eller lita på andra människor.

Kvinnors hemlöshet omtalas ofta som en dold hemlöshet. Vad man då refererar till är att kvinnor söker lösa sin logifråga på egen hand - t.ex. genom att bo tillfälligt hos bekanta (Järvinen 1992). Men kvinnornas hemlöshet är även dold på många andra sätt. Den är t.ex. dold politiskt genom att kvinnors situation och problem inte har getts någon uppmärksamhet och resurserna för kvinnorna är därmed knappa (Beijer 1998). I denna artikel har jag velat peka på en ytterligare dimension av det dolda i den kvinnliga hemlösheten - nämligen att dessa kvinnor inte vill se hemlösa ut och gör allt de kan för att dölja detta för omgivningens blickar. Det går alltså inte se på dem när de rör sig i staden att de inte har ett hem. Kvinnorna upplever så starkt att en identitet som hemlös som stigmatiserande och att bli sedd som hemlös är intimt förknippat med känslor av skam och förnedring. Och att bli sedd som hemlös är dessutom att i en bemärkelse inte 
bli sedd, att bli betraktad som någon man inte är eller inte vill vara. Flera upplever att omgivningens blick objektifierar dem och de har uttryckt att de känner sig utpekade som prostituerade, som ett socialt problem eller som stackars offer. Upprepade gånger har de också talat om att de upplever att andra människor känner en rädsla när de ser dem. Anna menar människor blir rädda därför att de inte vet någonting om hemlösa. $\AA$ andra sidan, när kvinnorna döljer sin hemlöshet, blir de inte heller sedda eftersom de då döljer en aspekt av deras liv som präglar hela deras vardag.

Kvinnorna måste hela tiden kämpa med sin egen självbild och omgivningens bild av dem. Detta gör att de också upplever ett starkt utanförskap - de känner att de blir stämplade som någon som är utanför - som är annorlunda. Deras utanförskap är inte valt och de känner sig inte annorlunda än dem som antas befinna sig inne i samhället. Istället är det andra människors blickar, offentliga och institutionella berättelser som säger att hemlösa står utanför samhället och för att komma in igen måste de anpassa sig efter samhällets regler. Samtidigt befinner sig hemlösa i allra högsta grad inne i samhällssystemet. Få människor tvingas så ofta redovisa sina levnadsförhållanden och ekonomiska situation för myndigheter och behandlingspersonal som de. Kvinnornas utanförskap är därför ett motsägelsefullt utanförskap genom att de känner att de behandlas som om de vore utanför samhället samtidigt som de upplever att de är kontrollerade av samhället. Deras berättelser om sig själva präglas därför av att de försöker hitta olika strategier för att hantera denna motsägelse av att vilja komma in (-omhus) samtidigt som de vill ut ur systemets kontroll.

\section{Summary The contradiction of being an outsider}

In many descriptions of the homeless condition we are told that the homeless live their lives "outside of society". This article focuses on the the notion of "outsiders" and relates it to the experiences of homeless women. Seven homeless women have been interviewed, and the article discusses their contradictionary experiences of being both "outside" and "inside" society. While they feel stigmatized as outsiders, they also feel that they are "inside" society in the sense that they feel controlled. This contradiction inherent in their experiences of being outsiders is then analysed in relation to authorities and public space. The article concludes that, on the one hand, the homeless women interviewed want to come "inside" society, in that they want the protection of their own walls and doors - in their own homes. On the other hand they seek to evade the control of the welfare system they feel themselves as victims of - to get out of the sites for societal control. 


\section{Litteratur}

Beijer,Ulla (1998) Hemlösa kvinnor i Stockholm. Stockholm:FOU-rapport.

Carlen, Pat (1996) Jigsaw. A political criminology of youth homelessness. Buckingham:Open University Press.

Fanon,Frantz (1995) Svart Hud,Vita Masker. Uddevalla:Daidalos.

George, Rosemary (1996) The Politics of Home. Postcolonial relocations and twentieth-centry fiction. Cambridge: Cambridge University Press.

Goffman, Ervin (1972) Stigma. Den avvikandes roll och identitet. Stockholm:Rabén \& Sjögren.

Goffman, Ervin (1974) Jaget och maskerna.En studie i vardagslivets dramatik. Stockholm:Rabén \& Sjögren.

Golden, Stephanie (1992) The Women Outside. Meanings and Myths of Homelessness. Berkeley:University of California Press.

Hanström, Maj-Britt (1991) På glänt? Bostads- och boendeförhållanden för kvinnor med missbruksproblem. Stockholm:Byggforskningsrådet.

Hopper, Kim (1991) "A Poor Apart: The distancing of Homeless Men in New York's History« i Social Research 58:1,107-132.

Hutson, Susan \& Liddiard, Mark (1994) Youth Homelessness: The Construction of a Social Issue. Basingstoke:MacMilliam.

Hydén, Lars-Christer (1995) „Det sociala misslyckandet som berättelse. Att återställa den moraliska ordningen."Socialvetenskaplig Tidskrift Nr3:194-207.

Johansson, Thomas (1997) Den skulpterade kroppen. Stockholm:Carlsson.

Jonsson, Stefan (1996) Andra Platser. Stockholm:

Norstedts

Järvinen, Margareta (1992)«Hemlöshetsforskning i

Norden« i Järvinen,M. \& Tigerstedt,C. red;

Hemlöshet $i$ Norden NAP.

Järvinen, Margareta (1993) De nye hjemlöse.
Kvinder,fattigdom og vold. Holte.Förlaget Socpol.

Marris, Peter (1990) The Politics of Insecurity.Attachment in private and public life London:Routledge.

Passaro, Joanne (1996) The Unequal Homeless.

Men on the street, Women in their place.

London:Routledge.

Rose,Gillian (1993) Feminism and Geography. The Limits of Geographical Knowledge.

London:Polity Press.

Sahlin, Ingrid (1992) Begreppet »hemlös". En kritisk granskning av använda definitioner.

Karlskrona:Boverket.

Sahlin, Ingrid (1998) The Staircase of Transition.

European Observatory on Homelessness. National Report from Sweden 1997.

Lund:Department of Sociology.

Sibley, David (1992) »Outsiders in society and space« i Anderson,K. \& Gale,F. red,: Inventing Places:Studies in Cultural Geography. London:Longman.

Skegg, Beverly (1997) Formations of Class and Gender. Becoming Respectable. London:Sage

Swärd, Hans (1999) "Att forska om utsatta" Socialvetenskaplig Tidskrift No 2:172-183.

Taylor, Gabriel (1985) Pride, Shame and Guilt: Emotions of SelfAssesment. Oxford:Claredon.

Watson,Sophie \& Austerberry, Helen (1986) Housing and Homelessness. A feminist perspective. London: Routledge and Keagan Paul.

Wagner, David (1993) Checkerboard Square. Culture and resistance in a homeless community. San Francisco:Westview Press.

Wright, Talmadge (1997) Out of Place: Homeless Mobilizations, Subcities and Contested Landscapes. Albany: State Univ. of New York Press.

Wurmser, Léon (1981) The Mask of Shame. Baltimore:The John Hopkins University Press 